\title{
Hubungan Keterampilan Proses Sains dan Kemampuan Berpikir Kritis pada Materi Suhu dan Kalor
}

\author{
Desi Fitria $^{1}$ \\ ${ }^{1}$ Sekolah Menengah Atas 12 Kota Jambi, Jambi, Indonesia
}

\begin{tabular}{l} 
Article Info \\
\hline Article history: \\
Received Mar 4, 2020 \\
Revised Mei 1, 2020 \\
Accepted Jul 5, 2020 \\
\hline
\end{tabular}

\section{Keywords:}

Fisika

Keterampilan Proses Sains

Kemampuan Berpikir Kritis

\begin{abstract}
ABSTRAK
Tujuan penelitian: Tujuan dari penelitian ini yaitu untuk melihat hubungan keterampilan proses sains dengan kemampuan berpikir kritis siswa SMAN 12 Kota Jambi pada materi suhu dan kalor (perubahan wujud).

Metodologi: Metode yang digunakan dalam penelitian ini adalah metode penelitian asosiatif kuantitatif dengan desain penelitian koresional Teknik penelitian yang digunakan adalah teknik purposive sampling. Instrumen penelitian yang digunakan adalah instrumen keterampilan proses sains dasar siswa yang terdiri dari 18 pernyataan dan instrumen tes kemampuan berpikir kritis pada materi suhu dan kalor yang terdiri dari 7 pernyataan. Responden terdiri dari 96 siswa kelas XI Mipa SMAN 12 Kota Jambi. Instrumen yang digunakan dalam penelitian ini menggunakan skala likert.
\end{abstract}

Temuan utama: Hasil penelitian yang dilakukan oleh peneliti pada keterampilan proses sains dasar siswa pada materi suhu dan kalor pokok bahasan perubahan wujud menghasilkan persentase $52,1 \%$ dengan kategori tidak baik dan kemampuan berpikir kritis siswa pada materi suhu dan kalor pokok bahasan perubahan wujud adalah sebesar $62.5 \%$ dengan kategori tidak baik. Berdasarkan nilai signifikansi yang dihasilkan maka dapat dikatakan bahwa hubungan pada keterampilan proses sains dasar siswa dengan kemampuan berpikir krtitis siswa pada materi suhu dan kalor pokok bahasan perubahan wujud adalah sangat kuat dengan pearson correlation ,963 dan signifikansi sebesar, 000 .

Keterbaruan penelitian: Keterbaruan dalam penelitian yaitu berupa melihat keterampilan proses sains dan kemampuan berpikir kritis yang dimiliki siswa SMAN 12 Kota Jambi.

This is an open access article under the $\underline{C C B Y-N C}$ license

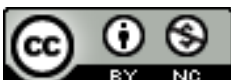

\section{Corresponding Author:}

Desi Fitria,

SMA 12 Kota Jambi, Jambi, Indonesia

Email: desi.f@gmail.com

\section{PENDAHULUAN}

Proses pembelajaran adalah pokok utama dari keseluruhan dunia pendidikan formal, karena melalui proses pembelajaran akan terjadinya transfer ilmu dari guru ke siswa dalam memenuhi tujuan pendidikan. Pendidikan adalah sesuatu yang sangat penting untuk dilakukan [1,2]. Pendidikan adalah kegiatan setiap manusia untuk mendapatkan kualitas hidup yang lebih baik [3,4]. Untuk mewujudkan tujuan pendidikan yang diharapkan, pendidik harus mampu mengembangkan nalar, kemampuan berpikir dan konsep diri siswa sehingga menciptakan pembelajaran yang bermakna bagi siswa [5-7]. Pembelajaran dikelas perlu didesain dengan melibatkan siswa untuk aktif belajar [8,9]. Salah satu upaya dalam bidang pendidikan untuk mencetak SDM yang berkualitas yaitu dengan membentuk budaya berpikir kritis pada siswa dalam proses 
pembelajarannya [10]. Strategi tersebut memberikan kekuatan bagi siswa dalam hal mengembangkan kemampuan berpikir dan keterampilan proses sains[11, 12].

Fisika dipandang sebagai suatu proses dan produk, sehingga strategi atau metode pembelajaran yang digunakan harus efektif dan efisien $[13,14]$. Fisika memainkan peran penting dalam menjelaskan berbagai fenomena yang terjadi di alam semesta $[15,16]$. Fisika telah menjadi salah satu mata pelajaran yang terkait dengan pendidikan sains $[17,18]$.

Materi fisika yang berhubungan dengan kehidupan sehari-hari yaitu suhu dan kalor [19-21]. Fisika adalah cabang ilmu yang memiliki keunikan dan karakteristik [22, 23]. Dalam kehidupan sehari-hari, suhu merupakan ukuran mengenai panas atau dinginnya suatu zat atau benda [24]. Banyak peralatan rumah tangga dibuat dengan memakai prinsip-prinsip perpindahan kalor [25, 26]. Misalnya peristiwa mendidihnya air setelah dipanaskan di atas kompor [27]. Pada materi suhu dan kalor siswa menunjukkam kemampuan kritisnya, Siswa lebih mengenal konsep dari contoh-contohnya karena dalam kehidupan sehari-hari siswa sering mengalami dan melihat contoh peristiwa suhu dan kalor [28, 29]. Jadi suhu dan kalor dapat mengembangkan kemampuan berpikir kritis peserta didik.

Tujuan diberlakukannya kurikulum 2013 diantaranya adalah mengembangkan kemampuan berpikir kritis dan keterampilan proses sains. Karena Saat ini, di Indonesia kemampuan berpikir kritis dan keterampilan proses sains menjadi persyaratan kurikulum 2013 [30]. Oleh karena itu, kurikulum 2013 harus fokus pada pembangunan pengetahuan dan mendorong siswa untuk menghasilkan informasi yang memiliki nilai atau makna bagi mereka untuk mengembangkan keterampilan baru [31]. Kurikulum 2013 membutuhkan desain pembelajaran yang berpusat pada siswa sehingga guru harus tahu bagaimana sifat siswa, dan mengetahui cara atau pendekatan yang tepat dalam mengikat kemampuan yang menjadi tujuan dalam pendidikan saat ini [32]. Salah satu cara untuk mengembangkan kemampuan berpikir kritis dan keterampilan proses sains melalui kegiatan praktikum.

Kegiatan praktikum berperan penting dalam membentuk keterampilan proses sains dan kemampuan berpikir kritis pada peserta didik. Keterampilan proses sains adalah keterampilan yang perlu ditanamkan pada praktikkan, dan dimiliki oleh peserta didik [33]. Keterampilan proses sains adalah keterampilan berpikir yang digunakan untuk menciptakan pengetahuan, menyelesaikan masalah dan merumuskan hasil [34]. Keterampilan proses sains peserta didik dapat dilihat dari kegiatan praktikum yang mengarah pada konsep dalam pembelajaran dan penerapan ilmu pengetahuan [35].

Keterampilan proses sains adalah alat yang digunakan peserta didik untuk menyelidiki dunia di sekitar mereka dan untuk membangun konsep-konsep sains [36]. Keterampilan proses sains adalah keterampilan yang melibatkan kognitif atau aspek intelektual, manual, sosial, mental dan fisik yang berfungsi sebagai alat yang diperlukan untuk pembelajaran yang efektif, pemecahan masalah, dan pengembangan individu dan kelompok [37]. Jadi dari penelitian diatas dapat disimpulkan bahwa keterampilan proses sains adalah perangkat kemampuan kompleks yang biasa digunakan oleh para ilmuwan dalam melakukan penyelidikan ilmiah ke dalam rangkaian proses pembelajaran

Dalam literasi pendidikan sains, keterampilan proses sains terbagi menjadi dua kelompok yaitu keterampilan proses sains dasar dan terintegrasi [38]. Keterampilan proses sains dasar meliputi observasi, klaifikasi, mengukur, predikasi, komunikasi dan menyimpulkan [39]. Sedangkan keterampilan proses sains teruntegrasi meliputi Identifikasi Variabel, Menyusun tabel data, Membuat grafik, Memperoleh dan memproses data, Mendeskripsikan hubungan antar variabel, Mengidentifikasi variabel secara operasional, Membuat hipotesis, Analisis percobaan, Merancang investigasi, dan Melakukan eksperimen [40]. Dari pengertian diatas menunjukkan bahwa dengan keterampilan proses, peserta didik berusaha menemukan dan mengembangkan kemampuan kognitif dan psikomotor. Sehingga keterampilan proses sains dapat menunjang peserta didik dalam mengembangkan kemampuan berfikir kritis.

Kemampuan berpikir yang dikembangkan melalui kegiatan pembelajaran aktif yaitu kemampuan berpikir kritis. Berpikir adalah proses yang diciptakan secara tidak sadar dalam diri seseorang [41]. Berpikir kritis adalah kegiatan berpikir yang dilakukan dengan mengoperasikan potensi intelektual untuk menganalisis, membuat pertimbangan dan mengambil keputusan secara tepat dan melaksanakannya secara benar [42]. Pemikir kritis mampu mencari, memahami, dan mengevaluasi pernyataan yang relevan secara logis dan rasional selama proses penyelesaian masalah atau pengambilan keputusan [43].

Berpikir kritis adalah berpikir yang reflektif secara mendalam dalam pengambilan keputusan dan pemecahan masalah untuk menganalisis situasi, mengevaluasi argumen, dan menarik kesimpulan yang tepat [44]. Berpikir kritis adalah kemampuan yang sangat penting bagi setiap individu, karena hampir semua aspek kehidupan membutuhkan kemampuan berpikir kritis [45]. Berpikir kritis itu penting dan harus dimiliki oleh setiap individu untuk menyelesaikan masalah kehidupan yang ada semakin kompleks di era globalisasi saat ini [46]. Oleh karena itu siswa harus mampu berpikir kritis sesusai tuntutan pendidikan saat ini.

Penerapan kemampuan berpikir kritis dalam pembelajaran sangat penting, hal ini sejalan dengan pendapat [47], kemampuan berpikir kritis adalah metode pembelajaran atau cara yang baik yang harus kita 
tanamkan dalam proses pembelajaran fisika. Pembelajaran fisika yang berpacu pada konsep-konsep memerluan pemahaman yang tinggi [48]. Fisika adalah cabang ilmu yang memiliki keunikan dan karakteristik [22]. Fisika dipandang sebagai suatu proses dan produk, sehingga strategi atau metode pembelajaran yang digunakan harus efektif dan efisien [49]. Fisika telah menjadi salah satu mata pelajaran yang terkait dengan konsep ilmiah [50]. Fisika memainkan peran penting dalam menjelaskan berbagai fenomena yang terjadi di alam semesta [15]. Fisika adalah ilmu pengetahuan yang mempelajari kejadiankejadian yang ada, baik yang dapat diamati secara langsung maupun tidak langsung [25]. Dengan demikian siswa dituntut harus mengikuti dan menguasai materi fisika yang diajarkan karena fisika berperan penting dalam mengembangkan kemampuan berpikir kritis.

Perkembangan kemampuan berpikir kritis siswa dalam pembelajaran fisika dapat kita lihat dari hasil belajarnya. Hasil penelitian sebelumnya menunjukkan bahwa berpikir kritis dalam pembelajaran fisika dapat meningkatkan prestasi siswa [51]. Kemampuan berpikir kritis mempengaruhi hasil belajar siswa. Siswa yang memiliki kemampuan berpikir kritis tinggi maka hasil belajarnya juga akan tinggi [52]. Semakin tinggi tingkat berpikir kritis siswa maka semakin besar hubungan fungsional yang signifikan terhadap hasil belajar fisika [53]. Pembelajaran fisika merupakan salah satu pelajaran yang dapat meningkatkan kemampuan berpikir kritis siswa $[21,54]$. Siswa akan merasakan pentingnya belajar melalui proses penerapan kompetensi dalam kehidupan sehari-hari, dan mereka akan sangat memahami materi apa yang mereka pelajari $[55,56]$.

Tujuan berpikir kritis yaitu untuk memperluas pandangan (cakrawala) peserta didik sebagai penunjang cita-citanya. Para pemikir kritis mampu mencari, memahami, dan mengevaluasi pernyataanpernyataan yang relevan secara logis dan rasional selama proses penyelesaian masalah atau pengambilan keputusan [43]. Penerapan kemampuan berpikir kritis dalam pembelajaran sangat penting, hal ini sejalan dengan pendapat [47], kemampuan berpikir kritis adalah metode pembelajaran atau cara yang baik yang harus kita tanamkan dalam proses pembelajaran fisika. Berdasarkan penjelasan diatas berpikir kritis dapat mengembangkan keterampilan proses sains pada peserta didik.

Pada penelitian ini peneliti melakukan penelitian mengenai Hubungan keterampilan proses sains dengan kemampuan berpikir kritis terhadap siswa di SMAN 12 Kota Jambi pada materi suhu dan kalor pada pokok bahasan perubahan wujud. Berdasarkan uraian diatas peneliti akan menganalisis hubungan keterampilan proses sains dengan kemampuan berpikir kritis siswa pada pembelajaran Fisika di SMAN 12 Kota Jambi. Tujuan dari penelitian ini yaitu untuk melihat hubungan keterampilan proses sains dengan kemampuan berpikir kritis siswa SMAN 12 Kota Jambi pada materi suhu dan kalor (perubahan wujud).

\section{METODE PENELITIAN}

Metode yang digunakan dalam penelitian ini adalah metode penelitian asosiatif kuantitatif dengan desain penelitian koresional. Desain korelasional adalah sebuah prosedur di mana peneliti mengukur hubungan antara dua atau lebih variabel menggunakan analgukuranisis statistik korelasional [57]. Desain penelitian ini digunakan sesuai dengan tujuan dari penelitian ini yaitu untuk mengetahui hubungan dari keterampilan proses sains siswa dengan kemampuan berpikir kritis pada materi suhu dan kalor pokok bahasan perubahan wujud. Variabel yang digunakan dalam penelitian ini dalah variabel keterampilan proses siswa yang terdiri atas indikator observasi, komunikasi, klasifikasi, pengukuran, kesimpulan, predikasi dan menggunakan variabel kemampuan berpikir kritis siswa yang terdiri atas indikator klasifikasi dasar, dasar dalam mengambil keputusan dan interferensi pada materi suhu dan kalor pokok bahasan perubahan wujud.

Penelitian ini juga menggunakan teknik statistik deskriptif untuk menganalisis data [58]. Data yang digunakan dalam penelitian ini adalah data kuantitatif. Penelitian kuantitatif adalah penelitian yang datanya berupa angka-angka dan dianalisis menggunakan data statistik [59]. Teknik penelitian yang digunakan adalah teknik purposive sampling. Instrumen penelitian yang digunakan adalah instrumen keterampilan proses sains dasar siswa yang terdiri dari 18 pernyataan dan instrumen tes kemampuan berpikir kritis pada materi suhu dan kalor yang terdiri dari 7 pernyataan. Responden terdiri dari 96 siswa kelas XI Mipa SMAN 12 Kota Jambi. Instrumen yang digunakan dalam penelitian ini menggunakan skala likert. Skala Likert digunakan untuk mengukur keterampilan proses sains siswa selama praktikum dengan model empat pilihan (empat skala) dengan kategori 1 = Sangat Tidak Baik, 2 = Tidak Baik, 3 = Baik, Dan 4 = Sangat Baik. Setelah data dihasilkan selanjutnya data dianalisis menggunakan statistik deskriptif, inferensial dengan menggunakan uji interval dan analisis correlation dengan menggunkan SPSS. Rentang pada keterampilan proses sains dasar siswa dengan kemampuan berpikir kritis siswa pada materi suhu dan kalor (perubahan wujud) dapat dilihat pada tabel berikut: 
Tabel 1. Rentang Interval pada keterampilan Proses Sains Dasar siswa dengan kemampuan berpikir kritis

\begin{tabular}{lll}
\hline \multirow{2}{*}{ Kategori } & Rentang & \\
\cline { 2 - 3 } & KBK & KPS \\
\hline Sangat Tidak Baik & $0.00-7.00$ & $18.0-31.50$ \\
Tidak Baik & $7.10-14.0$ & $31.51-45.0$ \\
Baik & $14.1-21.0$ & $45.1-58.50$ \\
Sangat Baik & $21.0-28.0$ & $58.51-72.0$ \\
\hline
\end{tabular}

\section{HASIL DAN PEMBAHASAN}

Hubungan pada keterampilan proses sains dasar siswa dengan kemampuan berpikir kritis pada materi suhu dan kalor pokok bahasan perubahan wujud dapat dilihat berdasarkan hasil dari analisis data yangtelah diperoleh. Hasil analisis data yang dilakukan akan memberikan informasi sesuai dengan tujuan dari penelitian ini. Data yang dianalisis menggunakan statistik deskriptif dapat dilihat pada Tabel 2 berikit :

Tabel 2. Hasil Analisis Statistik Deskriptif keterampilan Proses Sains Dasar siswa terhadap materi suhu dan kalor (perubahan wujud)

\begin{tabular}{llllll}
\hline \multicolumn{2}{c}{ Klasifikasi } & & & & \\
\cline { 1 - 3 } Kps Dasar & Indikator & Mean & Median & Min & Max \\
\hline & Observasi & 2,7292 & 3,000 & 7 & 23 \\
& Classification & 2,7396 & 3,0000 & 1,00 & 4,00 \\
& Mengukur & 2,6979 & 3,0000 & 3,00 & 12,00 \\
& Prediksi & 2,4167 & 3,0000 & 1,00 & 4,00 \\
& Komunikasi & 2,6770833 & 2,000 & 4,00 & 7,00 \\
& Menyimpulkan & 2,6979 & 3,0000 & 7,00 & 19,00 \\
\hline
\end{tabular}

Berdasarkan Tabel 2. yang dihasilkan bahwa nilai dari statistik deskriptif keterampilan proses sains dasar siswa terhadap materi suhu dan kalor pokok bahasan perubahan wujud diperoleh nilai mean terbesar yaitu pada indikator klasifikasi dengan nilai sebesar 2,7396 nilai median sebesar 3 pada indikator klasifikasi, nilai minumum sebesar 7 sedangkan nilai maksimum sebesar 23. Selanjutnya untuk persentase keterampilan proses sains dasar siswa.

Tabel 3. Persentase Keterampilan Proses Sains Dasar Siswa

\begin{tabular}{lllllll}
\hline \multirow{2}{*}{$\begin{array}{l}\text { Kps } \\
\text { Dasar }\end{array}$} & \multirow{2}{*}{ Indikator } & \multicolumn{5}{c}{ Kategori } \\
\cline { 3 - 6 } & Observasi & 2.1 & 44.8 & 31.3 & 21.9 & 100 \\
& Klasifikasi & 7,3 & 52,1 & 26 & 14,6 & 100 \\
& Mengukur & 11,5 & 37,5 & 29,2 & 21,9 & 100 \\
& Prediksi & 22,9 & 26 & 37,5 & 13,5 & 100 \\
& Komunikasi & 6,3 & 44,8 & 24 & 25 & 100 \\
& Menyimpulkan & 7,3 & 50 & 29,2 & 13,5 & 100 \\
\hline
\end{tabular}

Tabel 3 menunjukkan bahwa keterampilan proses sains siswa tergolong dalam kategori tidak baik dengan persentase tertinggi pada indikator klasifikasi sebesar 52,1\%. Selanjutnya untuk nilai statistik deskriptif dan persertase kemampuan berpikir kritis siswa terhadap materi suhu dan kalor (perubahan wujud).

Tabel 4. Hasil Analisis Statistik Deskriptif dan kemampuan berpikir kritis siswa terhadap materi suhu dan

\begin{tabular}{llllllll}
\multicolumn{8}{c}{ kalo (perubahan wujud) } \\
\hline Rentang & Kategori & f & \% & Mean & Median & Min & max \\
\hline $0.00-7.00$ & STB & 6 & 6,3 & & & & \\
$7.10-14.0$ & TB & 60 & 62,5 & 12,6979 & 13,0000 & 4,00 & 28,00 \\
$14.1-21.0$ & B & 27 & 28,1 & & & \\
$21.0-28.0$ & SB & 3 & 3,1 & & & \\
\hline Total & & & & & & 100,0 \\
\hline
\end{tabular}

Berdasarkan tabel 4. yang dihasilkan bahwa nilai dari statistik deskriptif dan persentase kemampuan berpikir kritis siswa terhadap materi suhu dan kalor pokok bahasan perubahan wujud untuk nilai mean yaitu 
12,6979 nilai media 13,000 nilai minimum 4,00 dan nilai maksimum 28,00 serta persentase kemampuan berpikir kritis sebesar $62,5 \%$ pada kategori tidak baik. Untuk hasil analisis data hubungan keterampilan proses sains dasar siswa dengan kemampuan berpikir kritis materi suhu dan kalor pokok bahasan perubahan wujud dapat dilihat pada Tabel 5 berikut:

Tabel 5. Hubungan KPS Dasar Siswa dengan kemampuan berpikir kritis siswa pada materi suhu dan kalor (perubaha wujud)

\begin{tabular}{ll}
\hline \multicolumn{2}{l}{ Hubungan KPS dengan KBK } \\
\hline Pearson Correlation &, $963^{* *}$ \\
Sig. (2-tailed) &, 000 \\
\hline
\end{tabular}

Berdasarkan Tabel 5. yang dihasilkan bahwa hasil analisis data hubungan keterampilan proses sains dasar siswa dengan kemampuan berpikir kritis pada materi suhu dan kalor pokok bahasan perubahan wujud memiliki korelasi yang sangat kuat dengan nilai ,963 dan nilai p-value antara keterampilan proses sains dengan kemampuan berpikir kritis adalah ,000.

Hasil data yang telah dianalisis menghasilkan bahwa pada keterampilan proses sains dasar siswa pada materi suhu dan kalor menghasilkan persentase sebesar 52,1\% pada indikator klasifikasi dengan kategori tidak baik. Dari hasil penelitian pada setiap indikator keterempilan proses sains dasar menunjukkan siswa memliki keterampilan proses sains yang rendah. Rendahnya keterampilan proses sains siswa disebabkan karena siswa jarang dilatih berdiskusi dalam mempelajari materi pelajaran ataupun praktikum [60]. Hal ini sesuai dengan penelitian [61] untuk meningkatkan keterampilan proses peserta didik melalui kegiatan pratikum yang mengarah pada keaktifan siswa dalam menemukan hal-hal baru. Akar masalahnya adalah pembelajaran lebih didominasi oleh guru sehingga siswa berperan sebagai objek pembelajaran. Akibatnya kurang memberikan pengalaman kepada siswa untuk mengembangkan keterampilan proses sains [62]. hal ini sejalan dengan wawancara yang telah peneliti lakukan.

Peneliti melakukan wawancara terhadap guru dan siswa untuk melihat keterampilan proses sains. Guru sering melakukan kegiatan praktikum namun tidak semua materi, karena fasilitas laboratorium terbatas untuk mendukung kegiatan praktikum sebagian besar siswa belum terampil dalam melakukan praktikum. Beberapa dari siswa mengatakan praktikum membuat belajar lebih bermakna karena melalui praktikum bukan hanya teori dan konsep yang dipelajari namun siswa bisa menemukan konsep yang telah ada. Sehingga sebagian besar siswa menuntut agar praktikum diadakan secara berkala.

Sedangkan hasil analisis kemampuan berpikir kritis menghasilkan persentase sebesar 62,5\% dengan kategori tidak baik. Berdasarkan hasil penelitian diperoleh bahwa siswa SMAN 8 Muaro Jambi tergolong dalam kategori tidak kritis. Rendahnya kemampuan berpikir kritis siswa ini antara lain dikarenakan pembelajaran yang diterapkan di sekolah masih didominasi oleh guru sehingga kurang melatih kemampuan berpikir kritis siswa dan rendahnya kemampuan berpikir kritis siswa itu karena siswa belum terbiasa mendapatkan soal dengan tingkat kognitif C4-C6 pada materi suhu dan kalor. Rendahnya kemampuan berpikir kritis siswa sejalan dengan hasil wawancara yang telah dilakukan oleh peneliti terhadap guru dan siswa bahwa siswa tidak memberikan respon yang optimal terhadap masalah yang diajukan oleh guru, siswa tidak mampu mendeskripsikan kondisi dalam persoalan yang sedang dibahas, siswa tidak memiliki rasa ingin tahu yang kuat, siswa tidak mampu menggunakan bahasa lisan secara variatif dan menarik untuk didengar serta tidak mampu berkomunikasi dengan lancar dan antusias. Pada saat pembelajaran berlangsung siswa lebih dominan diam dan siswa kurang aktif dalam proses pembelajaran karena saat pembelajaran berlangsung siswa lebih terbiasa memperhatikan, dan mencatat.

Pembelajaran fisika masih didominasi oleh guru, pembelajaran cenderung menghapal dari pada mengembangkan daya pikir sehingga siswa lemah dalam menyampaikan gagasannya sendiri, lemah dalam menganalisis, bergantung pada orang lain dibandingkan bertanggung jawab terhadap pilihannya sendiri [63]. Pengajaran sains di Indonesia sebagian besar berfokus pada menghafal sains konsep [64]. Jadi Guru harus mampu menciptakan pembelajaran yang melatih kemampuan berpikir kritis siswa pelatihan kemampuan berpikir kritis siswa yang dilakukan dengan baik akan meningkatkan minat belajar siswa dan percaya diri dalam memecahkan masalah sehingga hasil belajar juga maksimal. Sehingga perlu dilakukannya pembinaan yang lebih baik untuk meningkatkan kemampuan berpikir kritis siswa [64]. Jadi berpikir kritis sangat penting di miliki oleh siswa karena dengan kemampuan berpikir kritis siswa dapat meningkatkan hasil belajar fisika di sekolah dan mampu mengembangkan keterampilan proses sains [65].

Selanjutnya hubungan antara keterampilan proses sains dengan kemampuan berpikir kritis pada materi suhu dan kalo pokok bahasan perubahan wujud pada tabel 5. Berdasarkan nilai signifikansi yang dihasilkan maka dapat dikatakan bahwa hubungan keterampilan proses sains dengan kemampuan berpikir kritis pada materi suhu dankalor sangat kuat. Sehingga apabila keterampilan proses sains siswa rendah maka kemampuan berpikir kritis siswa juga rendah dan apabila keterampilan proses sains siswa tingga maka 
kemampuan berpikir kritis siswa juga tinggi. Hal ini terbukti pada penelitian ini bahwa siswa memilki keterampilan proses yang rendah dan kemampuan berpikir kritis yang rendah. Berdasarkan penelitian yang telah dilakukan [65] Peserta didik dengan keterampilan proses sains tinggi memiliki kemampuan berpikir kritis yang tinggi. Peserta didik dengan keterampilan proses sains sedang memiliki kemampuan berpikir kritis tinggi atau sedang. Peserta didik dengan keterampilan proses sains rendah memiliki kemampuan berpikir kritis sedang atau rendah. Jadi untuk meningkatkan keterampilan proses sains dan kemampuan berpikir kritis guru harus lebih kreatif dalam merancang dan mengembangkan perangkat pembelajaran agar mampu meningkatkan keterampilan proses sains dan kemampuan berpikir kritis siswa sehingga menjadi lebih baik. Guru harus melibatkan siswa dalam situasi pembelajaran yang mampu merangsang kemampuan siswa dalam berpikir kritis dan terampil melalui berbagai model pembelajaran aktif.

\section{KESIMPULAN}

Berdasarkan penelitian yang telah dilakukan dapat disimpulkan bahwa pada keterampilan proses sains dasar siswa pada materi suhu dan kalor pokok bahasan perubahan wujud menghasilkan persentase $52,1 \%$ dengan kategori tidak baik dan kemampuan berpikir kritis siswa pada materi suhu dan kalor pokok bahasan perubahan wujud adalah sebesar $62.5 \%$ dengan kategori tidak baik. Berdasarkan nilai signifikansi yang dihasilkan maka dapat dikatakan bahwa hubungan pada keterampilan proses sains dasar siswa dengan kemampuan berpikir krtitis siswa pada materi suhu dan kalor pokok bahasan perubahan wujud adalah sangat kuat dengan pearson correlation ,963 dan signifikansi sebesar ,000.

\section{UCAPAN TERIMA KASIH}

Peneliti mengucapkan terimakasih kepada seluruh pihak yang ikut serta dan berpartisipasi dalam pelakasanan penelitian ini.

\section{REFERENSI}

[1] M. Dwi Wiwik Ernawati, M. Damris, Asrial, And Muhaimin, "Development Of Creative Thinking Skill Instruments For Chemistry Student Teachers In Indonesia,” Int. J. Online Biomed. Eng., Vol. 15, No. 14, Pp. 2130, 2019.

[2] M. A. Haryanto, Bakar Abu, Ilahi, "Studi Perbandinganhasil Belajar Pada Materi Tata Nama Senyawa Kimia Antara Model Kooperatif Tipe Stad Dengan Jigsaw Kelas X Sma Negeri 3 Kuala Tungkal,” Vol. 7, Pp. 54-62, 2015.

[3] Maison, Darmaji, Astalini, D. A. Kurniawan, And P. S. Indrawati, "Science Process Skills And Motivation," Humanit. Soc. Sci. Rev., Vol. 7, No. 5, Pp. 48-56, 2019.

[4] Haryanto, "Pengembangan Instrumen Penilaian Afektif Pada Materi Laju Reaksi Di Prodi Pendidikan Kimia Fkip Universitas Jambi,” Pros. Semirata, Pp. 451-460, 2015.

[5] R. Rachmadtullah, "Kemampuan Berpikir Kritis Dan Konsep Diri Dengan Hasil Belajar Pendidikan Kewarganegaraan Siswa Kelas V Sekolah Dasar,” J. Pendidik. Dasar, Vol. 6, No. 2, P. 287, 2015.

[6] D. Melisa, "Identifikasi Konsentrasi Siswa Di Sman 10 Batang Hari," Vol. 1, No. 1, Pp. 6-11, 2019.

[7] S. Tanti, Utu Rahim, Hafiludin, "Pengaruh Model Problem Based Learning Terhadap Kemampuan Pemecahan Masalah Matematis Siswa Kelas Vii Smp Negeri 14 Kendari,” J. Penelit. Pendidik. Mat., Vol. 8, No. 3, Pp. 169182, 2020.

[8] N. H. Ridha Unnafi Walfajri, "Peningkatan Kemampuan Berpikir Kritis Dan Hasil Belajar Tematik Muatan Ipa Melalui Model Problem Based Learning Kelas 5 Sd," J. Basicedu, Vol. 3, No. 1, Pp. 16-20, 2019.

[9] R. Abdurrahman, Gardjito, Budiarti, "Pengembangan Lembar Kegiatan Siswa Berbasis Penemuan Terbimbing Pada Materi Struktur Dan Fungsi Jaringan Tumbuhan Kelas Xi Sma.,” Vol. I, No. September, Pp. 1-8, 2015.

[10] R. S. B. Adek Fujika, Evita Anggereini, "Analisis Kemampuan Berpikir Kritis Siswa Sma N 5 Kota Jambi Melalui Pembelajaran Berbasis Masalah Pada Konsep Pencemaran Lingkungan,” J. Biodik, Vol. 1, No. 1, Pp. 1-10, 2015.

[11] A. Budiarti Retni S, Sadikin, "Pengaruh Kartu Kwartet Animalia Dengan Model Tgt Terhadap Pemahaman Materi Taksonomi Hewan Siswa Sman 8 Kota Jambi,” Biodi, Vol. I, No. 1, Pp. 1-9, 2015.

[12] B. Harlis, Retni S, "Biodik: Jurnal Ilmiah Pendidikan Biologi Development Of Algae Textbooks In Monera And Protista Taxonomy Subjects For Biology Education Students Pengembangan Buku Ajar Alga Pada Mata Kuliah Taksonomi Monera Dan Protista Bagi Mahasiswa Pendidikan Biologi R,” Biodik, Vol. 5, No. 3, Pp. 215-224, 2019.

[13] Juita, "Identifikasi Konsentrasi Belajar Siswa Di Sekolah Menengah Atas," J. Phys. Educ., Vol. 1, No. 1, Pp. 24 29, 2020.

JEE. Vol. 1, No. 3, Juli 2020: 83 - 90 
[14] T. Tanti, "Konstruksi Dan Validasi Bahan Ajar Fisika Berbasis Problem-Based Learning (Pbl) Untuk Meningkatkan Keterampilan Generik Siswa," J. Teach. Learn. Phys., Vol. 5, No. 1, Pp. 28-34, 2020.

[15] L. R. S. Maison, Astalini, Dwi Agus Kurniawan, "Maison, Astalini, Dwi Agus Kurniawan, Lintang Rofiatus Sholihah," Vol. 10, No. 1, Pp. 160-167, 2018.

[16] Tanti, Maison, A. Mukminin, Syahria, A. Habibi, And Syamsurizal, "Exploring The Relationship Between Preservice Science Teachers' Beliefs And Self-Regulated Strategies Of Studying Physics: A Structural Equation Model,” J. Turkish Sci. Educ., Vol. 15, No. 4, Pp. 79-92, 2018.

[17] A. Rahayu And D. D. Romadona, "Deskripsi Implikasi Sosial Dari Fisika, Sikap Terhadap Penyelidikan Dalam Fisika Dan Adopsi Dari Sikap Ilmiah,” Vol. 1, No. 1, 2020.

[18] Z. P. Utama, M. Maison, And A. Syarkowi, “Analisis Kemampuan Bernalar Siswa Sma Kota Jambi,” J. Penelit. Pembelajaran Fis., Vol. 9, No. 1, P. 1, 2018.

[19] R. W. W. Maison, Ida Cuci Safitri, "Identification Of Misconception Of High School Students On Temperature And Calor Topic Using Four-Tier Diagnostic Instrument," Vol. 11, No. 2, Pp. 195-202, 2019.

[20] R. Dewi, R. S. Budiarti, And M. Aina, "The Development Of Learner Activity Sheet- Carged Character Education With A Learning Model Of Guided Inquiry On Material Of Bacteria For Students Of Class X High School," Biodik, Vol. 3, No. 1, Pp. 17-26, 2017.

[21] T. Tanti, J. Jamaluddin, And B. Syefrinando, "Pengaruh Pembelajaran Berbasis Masalah Terhadap Beliefs Siswa Tentang Fisika Dan Pembelajaran Fisika," J. Ilm. Pendidik. Fis. Al-Biruni, Vol. 6, No. 1, P. 23, 2017.

[22] Maison, Syahrial, Syamsurizal, And Tanti, "Learning Environment, Students' Beliefs, And Self-Regulation In Learning Physics: Structural Equation Modeling,”Vol. 18, No. 3, Pp. 389-403, 2012.

[23] S. Idawati Supu, Baso Usman, Selviani Basri, "Pengaruh Suhu Terhadap Perpindahan Panas Pada Material Yang Berbeda," J. Din., Vol. 07, No. 1, Pp. 62-73, 2016.

[24] E. Hadi And A. Yani, "Identifikasi Miskonsepsi Materi Fisika Suhu Dan Kalor Menggunakan Cri ( Certainty Of Response Index ) Pada Peserta Didik Kelas Xi Mia Sma Negeri 8 Bulukumba,” No. 1991, Pp. 44-54, 2018.

[25] Syamsurizal, Haryanto, And N. Chairani, "Pengembangan E-Modul Berbasis Keterampilan Proses Sains Pada Materi Kesetimbangan Kimia Untuk Tingkat Sma," Pros. Semirata 2015 Bid. Mipa Bks-Ptn Barat Univ. Tanjungpura, Pp. 655-661, 2015.

[26] S. L. P. P. Lestari, "Analisis Konsepsi Dan Perubahan Konseptual Suhu Dan Kalor Pada Siswa Sma Kelas Unggulan,” Unnes Phys. Educ. J., Vol. 3, No. 3, Pp. 77-83, 2014.

[27] N. Sofiana, N. M. Dp, And S. E. Nugroho, "Pengembangan Evaluasi Peta Konsep Dalam Pembelajaran Inkuiri Pada Pokok Bahasan Kalor,” Upej (Unnes Phys. Educ. Journal), Vol. 1, No. 1, 2012.

[28] Retno Herlis, Budiarti, "Pengembangan Bahan Ajar Praktikum Dan Instrumen Penilaian Berbasis Keterampilan Proses Sains Pada Mata Kuliah Mikologi Program Studi Pendidikan Biologi Universitas Jambi,” Biodik, Vol. 3, No. 2, Pp. 102-112, 2017.

[29] R. Wahyudi, D. Rukmini, D. Anggani, And L. Bharati, "English Education Journal Developing Discovery Learning-Based Assessment Module To Stimulate Critical Thinking And Creativity Of Students' Speaking Performance," English Educ. J., Vol. 9, No. 2, Pp. 2019-172, 2019.

[30] H. A. Alismail And P. Mcguire, "21 St Century Standards And Curriculum: Current Research And Practice," J. Educ. Pract., Vol. 6, No. 6, Pp. 150-155, 2015.

[31] R. D. Yediarani, M. Maison, And A. Syarkowi, "Scientific Reasoning Abilities Profil Of Junior High School Students In Jambi,” Indones. J. Sci. Educ., Vol. 3, No. 1, P. 21, 2019.

[32] S. Wahyuni, I. Indrawati, S. Sudarti, And W. Suana, "Developing Science Process Skills And Problem-Solving Abilities Based On Outdoor Learning In Junior High School,” J. Pendidik. Ipa Indones., Vol. 6, No. 1, Pp. 165$169,2017$.

[33] A. Aydın, "International Journal Of Education And Practice Representation Of Science Process Skills In The Chemistry," Vol. 1, No. 5, Pp. 51-63, 2013.

[34] S. Karamustafaoğlu, "Improving The Science Process Skills Ability Of Science Student Teachers Using I Diagrams," Eurasian J. Phys. Chem. Educ, Vol. 3, No. 1, Pp. 26-38, 2011.

[35] N. Gultepe, "High School Science Teachers' Views On Science Process Skills," Int. J. Environ. Sci. Educ., Vol. 11, No. 5, Pp. 779-800, 2016.

[36] M. G. Nugraha, S. Utari, D. Saepuzaman, F. N. Solihat, And K. H. Kirana, "Development Of Basic Physics Experiments Based On Science Process Skills (Sps) To Enhance Mastery Concepts Of Physics Pre-Service Teachers In Melde's Law," J. Phys. Conf. Ser., Vol. 1280, No. 5, 2019.

[37] N. Hırça, "The Influence Of Hands On Physics Experiments On Scientific Process Skills According To Prospective Teachers' Experiences," Eur. J Phys. Educ., Vol. 4, No. 1, Pp. 1-9, 2012.

[38] Remziye Ergul, Y. Simsekli, S. Calis, Z. Ozdilek, S. Gocmencelebi, And M. Sanli, "The Effects Of Inquiry-Based Science Teaching On Elementary School Students' Science Process Skills And Science Attitudes,” Bulg. J. Sci. Educ. Policy, Vol. 5, No. 1, Pp. 48-69, 2011. 
[39] F. D. And N. Azizoğlu*, "Investigation Of The Students ' Science Process Skill Levels In Vocational Schools : A Case Of Bal I Kesir,” Necatibey Fac. Educ. Electron. J. Sci. Math. Educ., Vol. 4, No. 2, Pp. 79-109, 2010.

[40] J. A. D. Rahmy Zulmaulida, Wahyudin, "Watson-Glaser' S Critical Thinking Skills Watson- Glaser' S Critical Thinking Skills," 2nd Int. Conf. Stat. Math. Teaching, Res., Pp. 1-6, 2018.

[41] M. Zunanda And K. Sinulingga, "Pengaruh Model Pembelajaran Berbasis Masalah Dan Kemampuan Berpikir Kritis Terhadap Keterampilan Pemecahan Masalah Fisika Siswa Smk," J. Pendidik. Fis., Vol. 4, No. 1, P. 63, 2015.

[42] A. Shaw Et Al., "Thinking Critically About Critical Thinking: Validating The Russian Heighten ${ }^{\circledR}$ Critical Thinking Assessment," Stud. High. Educ., Vol. 5079, 2019.

[43] M. Mason, "Critical Thinking And Learning," Educ. Philos. Theory, Vol. 39, No. 4, Pp. 339-349, 2007.

[44] M. M. E. Fitriatus Sholihah, Siti Inganah, "Analysis Of Critical Thinking Skills By Homeschooling's Students In Solving Mathematical Problem,” Math. Educ. J., Vol. 1, No. 2, P. 41, 2017.

[45] M. D. W. Ernawati, D. Muhammad, A. Asrial, And M. Muhaimin, "Identifying Creative Thinking Skills In Subject Matter Bio-Chemistry,” Int. J. Eval. Res. Educ., Vol. 8, No. 4, Pp. 581-589, 2019.

[46] R. Syafitri, R. Asyhar, And ) Asrial, "Pengaruh Model Inquiry Training Dan Berpikir Kritis Terhadap Kemampuan Berpikir Ilmiah Mahasiswa Pada Mata Kuliah Kimia Dasar The Effescts Of Inquiry Training Model And Critical Thingking To The Students's Scientific Thingking Skills On The Subject Of Che,” Vol. 5, No. 1, 2016.

[47] A. R. Putri, M. Maison, And D. Darmaji, "Kerjasama Dan Kekompakan Siswa Dalam Pembelajaran Fisika Di Kelas Xi Mipa Sma Negeri 3 Kota Jambi,” Edufisika, Vol. 3, No. 02, Pp. 32-40, 2018.

[48] S. P. Astuti, "Pengaruh Kemampuan Awal Dan Minat Belajar Terhadap Prestasi Belajar Fisika," Form. J. Ilm. Pendidik. Mipa, Vol. 5, No. 1, Pp. 68-75, 2015.

[49] Astalini, D. A. Kurniawan, Darmaji, L. R. Sholihah, And R. Perdana, "Characteristics Of Students' Attitude To Physics In Muaro Jambi High School,” Humanit. Soc. Sci. Rev., Vol. 7, No. 2, Pp. 91-99, 2019.

[50] Y. Mulyono, "Critical Thinking Skills Of Physics Education Students Through Ctl-Based Fundamental Biology," Vol. 2, No. 1, Pp. 65-76, 2018.

[51] A. F. N. L. Siti Komariyah, "Pengaruh Kemampuan Berpikir Kritis Terhadap Hasil Belajar Matematika," $J$. Penelit. Pendidik. Dan Pengajaran Mat., Vol. 4, No. 2, Pp. 55-60, 2018.

[52] M. Husnah, "Hubungan Tingkat Berpikir Kritis Terhadap Hasil Belajar Fisika Siswa Dengan Menerapkan Model Pembelajaran Problem Based Learning,” J. Phys. Sci. Learn., Vol. 01, No. 2, Pp. 10-17, 2017.

[53] Maison et al., "Learning In Nature Science: Social Implications, Normality Of Scientist, Attitudes Towards Investigation Of Natural Science, And Interest Adds To Science Learning Time,” Int. J. Sci. Technol. Res., Vol. 8, No. 12, Pp. 1478-1484, 2019.

[54] S. Ahmad Anis Abdullah, "Meningkatkan Kemampuan Berpikir Kritis Melalui Pembelajaran Statistika Berbasis Pendidikan Politik Di Lingkungan Sekolah,” J. Gantang, Vol. Ii, No. 1, Pp. 1-10, 2017.

[55] N. K. Haryanto, Harizon, Rantih, "Pengembangan Instrumen Penilaian Keterampilan Proses Dan Sikap Ilmiah Pada Materi Termokimia Kelas Xi Mia Sma Negeri 10 Kota Jambi,” J. Indones. Soc. Integr. Chem., Vol. 8, No. 1, 2015.

[56] J. W. Creswell, "Research Design: Pendekatan Kualitatif, Kuantitatif, Dan Mixed," Yogyakarta: Pustaka Pelajar, 2013.

[57] Sugiyono, Metode Penelitian Kombinasi. Yogyakarta: Alfabeta, 2013.

[58] N. Alfianika, Buku Ajar Metode Penelitian Pengajaran Bahasa Indonesia. Yogyakarta: Deepublish, 2018.

[59] S. Özgelen, "Students' Science Process Skills Within A Cognitive Domain Framework," Eurasia J. Math. Sci. Technol. Educ., Vol. 8, No. 4, Pp. 283-292, 2012.

[60] Darmaji, D. A. Kurniawan, Astalini, A. Lumbantoruan, And S. C. Samosir, "Mobile Learning In Higher Education For The Industrial Revolution 4.0: Perception And Response Of Physics Practicum," Int. J. Interact. Mob. Technol., Vol. 13, No. 9, Pp. 4-20, 2019.

[61] A. Muhlisin, H. Susilo, M. Amin, And F. Rohman, "Improving Critical Thinking Skills Of College Students Through Rms Model For Learning Basic Concepts In Science," Asia-Pacific Forum Sci. Learn. Teach., Vol. 17, No. 1, 2016.

[62] B. A. Prayitno, D. Corebima, H. Susilo, S. Zubaidah, And M. Ramli, "Closing The Science Process Skills Gap Between Students With High And Low Level Academic Achievement," J. Balt. Sci. Educ., Vol. 16, No. 2, Pp. 266-277, 2017.

[63] G. Çavdar And S. Doe, "Learning Through Writing: Teaching Critical Thinking Skills In Writing Assignments," Ps - Polit. Sci. Polit., Vol. 45, No. 2, Pp. 298-306, 2012.

[64] S. Husein, L. Herayanti, And G. Gunawan, "Pengaruh Penggunaan Multimedia Interaktif Terhadap Penguasaan Konsep Dan Keterampilan Berpikir Kritis Siswa Pada Materi Suhu Dan Kalor,” J. Pendidik. Fis. Dan Teknol., Vol. 1, No. 3, P. 221, 2017.

[65] A. J. Nugraha, H. Suyitno, And E. Susilaningsih, "Analisis Kemampuan Berpikir Kritis Ditinjau Dari Keterampilan Proses Sains Dan Motivasi Belajar Melalui Model Pbl,” J. Prim. Educ., Vol. 6, No. 1, Pp. 35-43, 2017.

JEE. Vol. 1, No. 3, Juli 2020: 83 - 90 